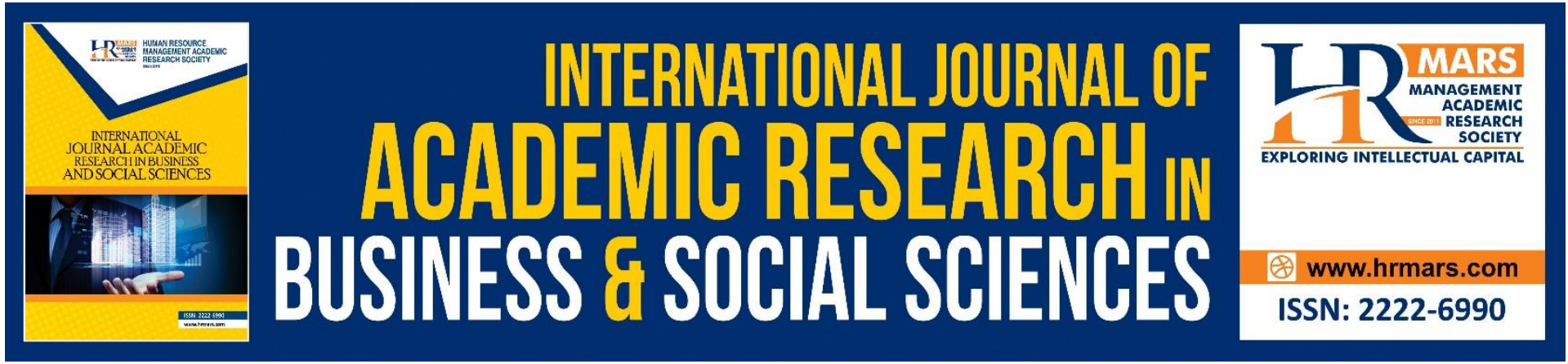

\title{
Influence of Change Management Pratices on Performance of Hotels in Nairobi County, Kenya
}

Naomi Chemutai Rotich, Jared Deya

To Link this Article: http://dx.doi.org/10.6007/IJARBSS/v11-i7/10669

DOI:10.6007/IJARBSS/v11-i7/10669

Received: 24 May 2021, Revised: 28 June 2021, Accepted: 13 July 2021

Published Online: 26 July 2021

In-Text Citation: (Rotich \& Deya, 2021)

To Cite this Article: Rotich, N. C., \& Deya, J. (2021). Influence of Change Management Pratices on Performance of Hotels in Nairobi County, Kenya. International Journal of Academic Research in Business and Social Sciences, 11(7), 1653-1671.

Copyright: (c) 2021 The Author(s)

Published by Human Resource Management Academic Research Society (www.hrmars.com)

This article is published under the Creative Commons Attribution (CC BY 4.0) license. Anyone may reproduce, distribute, translate and create derivative works of this article (for both commercial and non-commercial purposes), subject to full attribution to the original publication and authors. The full terms of this license may be seen at: http://creativecommons.org/licences/by/4.0/legalcode

Vol. 11, No. 7, 2021, Pg. 1653 - 1671

http://hrmars.com/index.php/pages/detail/IJARBSS

JOURNAL HOMEPAGE

Full Terms \& Conditions of access and use can be found at http://hrmars.com/index.php/pages/detail/publication-ethics 


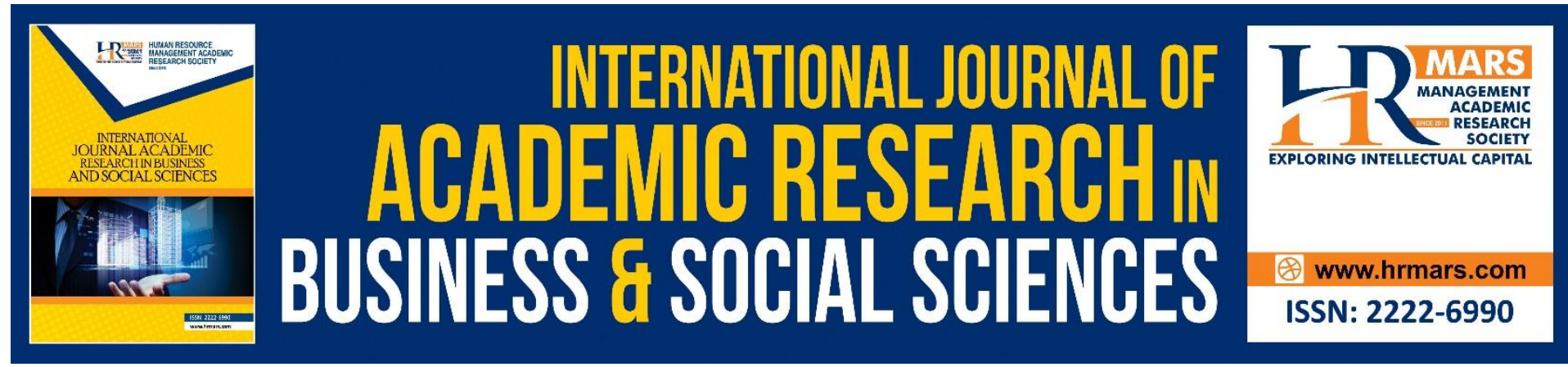

\title{
Influence of Change Management Pratices on Performance of Hotels in Nairobi County, Kenya
}

\author{
Naomi Chemutai Rotich, Dr. Jared Deya \\ College of Human Resource and Development, Jomo Kenyatta University of Agriculture and \\ Technology
}

\begin{abstract}
The current study sought to establish how change management practices influences performance of hotel in Nairobi County, Kenya. The study specifically aimed at establishing the influence of communication, employee engagement, leadership and resource dedication on performance of the hotel in Nairobi County, Kenya. The theories that anchors the study comprised of Communication Theory, Self-Determination Theory, Path Goal Leadership Theory and Resource Based View Theory. The study employed a descriptive research design and the target population comprised of 44 hotels distributed in Nairobi County with ratings of one to five stars as formulated in Tourism Regulatory Authority Hotel Classifications 2018. A census approach was adopted in the study. Primary data was collected through questionnaires containing close ended questions while a secondary data collection sheet was used to collect secondary data. The data collected was analyzed by employing both inferential analysis and descriptive statistics using MS Excel and SPSS software V22. A pilot study was conducted on 4 randomly selected hotels to assess the validity and reliability of the data collection instrument. The study established that communication, employee engagement, leadership and resources dedication positively and significantly influence performance levels of the hotels as shown by Beta values of $0.298,0.321,0.387$ and 0.459 respectively. This implies that increase in one unit of each of the variables results to an increase in the performance levels with the respective beta values. The study recommended that there is a need for hotels to enhance their communication practices while implementing changes, to enhance their employee engagement practices while implementing changes, to enhance their leadership practices while implementing changes and to enhance their resources dedication practices while implementing changes since the practices positively influences the performance levels.
\end{abstract}

Keywords: Communication, Employee Engagement, Leadership, Resource Dedication, Change Management and Performance of Hotels

\section{Background of the Study}

The level of performance of an organization forms the basis through which the organization gains people's commitment in steering it towards realizing the set organizational goals. Additionally, the level of performance of the organization bears implications to its health and thus its ultimate survival (Richard et al., 2012). According to Panda(2011), increased 
competition, reduced resources, technological changes, changes in customers' demands, mounting employees' expectations and globalization have all merged in a way that organizations are been expected post high performance despite the surrounding challenging environment. However, Ochuti, (2014) asserts that in the prevailing competitive environment, firms seeking to improve and maintain their performance levels need to adopt change management practices to fit and survive in the competitive and dynamic operational environment. Chapman (2015) defines change management practices as the process of redesigning and restructuring the activities within organization to keep abreast of the prevailing challenges while meeting the customers' needs. In another dimension, Crane (2010) views change management practices as a set of managerial actions and decisions which an organization undertakes to manage changes in the operational environmental.

The practices are designed aiming at setting course of action of a firm, identifying strategies to be adopted to compete favorably in the market place and the process of organizing activities internally. According to Chapman (2015), change management practices lays emphasis on formulation of organizational strategies and management plans in the context of set organizational objectives and goals which responds to the dynamic nature of the external environment of the organization. Crane (2010) notes that the overall theme pertaining to the adoption of change management practices is the integration of all functions of the institution, adherence to the organizational goals and positive response to the external operational environment. The environment in which hotels operates is characterized by unpredictable and rapid changes in attitudes of the customers making adoption of change management practices inevitable in the sector (Gathara, 2018). Additionally, the operational environment of hotels characterized by uncertainty in political and economic conditions, take-overs, fierce competition, acquisitions, government interventions, technological developments and changes in social attitudes creates a volatile environment which poses a threat to their existence and survival. According to Hilman, and Mohamed (2011), the only way the hotels can perform efficiently and effectively is through the adoption of change management practices with positive responsiveness to the prevailing dynamic environment. This study seeks to establish how change management practices influences performance of hotel in Nairobi County, Kenya.

\section{Statement of the Problem}

The economy of Kenya largely relies on the growth and development of key economic sectors such as tourism. According to KNBS (2019), tourism contribution to Kenyan GDP was 8.8\%, 8.9\%, 9.0\% and 9.7\% in 2018, 2017, 2016 and 2015 respectively. However, the tourism sector which vastly comprise of hotels has witnessed turbulent times in operations which has been associated with performance challenges in the sector. Hotels are exposed to challenges such as stiff competition, changes in customer demands in terms of services, seasonality of hotel services and a decline in the world tourism has negatively affected the level of sales amongst hotels since a large section of the hotel industry relies on international markets(Muhinyu \& Gudda, 2019). Remarkably, Covid-19 pandemic has threatened survival of hotels which has resulted to massive employees retrenchment and closure of hotel business. The pandemic has contributed to imposition of strict travel restrictions, and grounding of airlines by countries which has significantly reduced the number of tourists visiting the country. Available data from the Ministry of Tourism (2020) shows that the first quarter of 2020 experienced a reduction of $22 \%$ of tourists arrival in the country with March 2020 experiencing a 57\% reduction on international arrivals. This according to the ministry translates into a loss of 
about 67 million arrivals and approximately USD 80 million in receipts. In terms of contribution to GDP, the sector's contribution levels has continuously declined (World Bank Report, 2018). In 2014 for instance, the sector accounted for 10.2\% of GDP which decreased to $9.7 \%$ in 2015 . In 2016, the sector accounted for $9.0 \%$ of GPD which decreased to $8.9 \%$ in 2017 followed by a further decline to $8.8 \%$ in 2018(WB, 2018). According to Muhinyu and Gudda, (2019) complexity in managing hotels attributed to turbulent operational environment has further worsened the performance level. To experience exemplary performances, stand the stiff competition and respond to turbulent operational environment, there is a need to adopt appropriate change management practices in the hotel industry.

Gathara (2018) notes that adoption of change management practices aims at enabling a firm achieve the desired performance results within the desired timeframe. The current study seeks to establish how change management practices influences performance with a focus on hotel industry in Kenya. The study is further motivated by research gaps from past studies on the theme of the study. Fok-Yew and Ahmad (2014) focused on establishing how change management impact operational excellence in electrical and electronic sector in Malaysia. The study focused on change practices such as HR practices, leadership styles and cultural trait involvement and found these practices to positively and significantly impact performance excellence. The locale of the study was Malaysia. Ogohi (2019) sought to evaluate how change management practices affects performance of firms in Nigeria. The study revealed that change management practices bear a positive impact on performance. This study was however conducted in Nigeria. Wachira and Anyieni (2017) focused on establishing how change management practices impacts performance of Teachers Service Commission in Kenya. The study focused on communication as a change management practice and established that it bears a positive effect on performance. This study however focused on the Teachers Service Commission. These studies were conducted in various contexts and focused on different concepts thus presenting both contextual and conceptual knowledge gaps which the current study seeks to fill by establishing how change management practices influences performance of hotel in Nairobi County, Kenya.

\section{Objectives of the Study}

i. To assess the influence of communication on performance of hotel in Nairobi County, Kenya

ii. To determine the influence of employee engagement on performance of hotel in Nairobi County, Kenya

iii. To examine the influence of leadership on performance of hotel in Nairobi County, Kenya

iv. To evaluate the influence of resource dedication on performance of hotel in Nairobi County, Kenya

\section{Literature Review \\ Theoretical Review \\ Communication Theory}

The theory was developed by Weaver and Shannon in 1949 which aimed at providing a platform for receiving and sending of messages efficiently through an established channel and assessing problems associated with the communication. According to the theory, communication comprises of a sender where the message originates, a medium of transmission where the message passes through (exposed to distortions and noise) and the 
receiver of the message (the destination of the message). The main goal of the receiver is to decode the message for the purpose of understanding its contents. A communication is considered successful and complete when the intended receiver decodes the message and understands the intents of the sender. Remarkably, communication is viewed as more effective when the receiver understands the full meaning of the sent message and acts in respect to the sender's desires. This is achieved when the receiver acknowledges having received the message and having understood its contents through a reply. Mason(1978) initially employed the communication model in conceptualizing the performance of channel for communication.

In his conceptualization, Mason (1978) proposed a communication framework characterized with three success criteria deemed necessary but not sufficient enough in capturing performance changes. The criteria comprise of technical which defines the level of accuracy of a message when been transferred to the receiver, semantic which defines how exactly the receiver receives the projected message and effectiveness which shows the level of effectiveness of the communication channel in respect to the benefits stakeholders (sender or receiver) accrues. The study adopts the communication theory to interpret the need of effective communication in a hotel. According to the theory, communication ought to be clear and precise from the sender to the receiver. Additionally, there should be clear communication channel through which the message passes through from the sender to the receiver. The channel should be away from distortions such as noise to ensure that the intended message is received as planned. In a hotel set up, there is a need for existence of a clear means of communication between the management and employees in case of changes in operations. This enables employees to adjust fully to the changes.

\section{Self-Determination Theory}

The theory was proposed by Richard Ryan and Edward Deci in 1985 and has been frequently refined and elaborated by different scholars from various countries. The theory suggests that employees are driven by a need to gain fulfillment and growth. While external rewards usually drives employees to act, the theory primarily focuses on internal motivational sources such as the urge of gaining knowledge. The theory further postulates that certain feelings amongst employees derived from the firm contributes to employees psychological growth. The feelings comprise of the need to master assigned tasks and gain different skills, the need of experiencing an aspect of attachment and belonging and the need of being in control of own goals and behaviors. According to the theory, one of the main dispositional factor associated with satisfaction of needs and autonomous regulation with the possibility of contributing to high levels of engagement is general causality orientation.

This according to Ryan and Deci (1985) comprise of the tendency of employees to regulate themselves and scrutinize situations of value and which supports self-initiations. The theory considers general causality as a factor for consideration by organization during selection process as a strategy for promoting high employee engagement levels. However, the theory notes that selection processes alone might not be sufficient in achieving desired levels of employees engagement. Deci and Gagne (2005) notes that management practices, job design and reward systems plays a critical role in satisfying the needs of employees and in promoting autonomy in regulation. The theory explores on the need of fully engaging employees in certain management areas to create a sense of belonging contributes to realization of set organizational goals. The management bears the responsibilities of engaging employees especially in making decisions that touches them. In instances of projected changes, the level 
of success or failure of the proposed changes depends on the degree to which the management engages employees.

\section{Path Goal Leadership Theory}

House and Mitchell(1974) propounded the theory and suggested that the functional roles of leaders entails setting and illuminating goals in the course of running operations while in cooperation with other subordinates. Consequently, the leader bears the responsibilities of helping the subordinates establish appropriate path to trail to realize the set performance goals while at the same time eliminating possible barriers that may prevent achievement of success. According to the theory, an organization is surrounded by situational factors acting as key contributors to efficient and effective leadership traits on subordinates such as their abilities, needs, self-confidence and aspects of work place environment including tasks, reward systems, and relationships amongst employees, which play a pivotal role in navigating a firm towards a desired change(Schuler, 1990). House and Mitchell(1974) further asserts that leaders behaviors can be categorized into five different styles: supportive, participative, instrumental, achievement oriented and transformational leadership.

According to the theory, the behavior of leaders is only acceptable and providing satisfaction to subordinates only if it forms the basis for satisfaction and motivation on the side of subordinates. The behavior of leaders according to Evans (1970) increases the efforts of subordinates in their attempts of implementing changes. Remarkably, leaders act as link on the route to be followed while implementing changes between. This is done through defining roles, tasks and positions, elimination of obstacles to performances, involving and enlisting group members in setting goal, promoting group cohesiveness and team efforts and minimizing stress and external controls. This is realized by making expectations clear and enhancing realization of expectations amongst the members. The theory contributes to the current study by showcasing the need of having the right leaders with appropriate leadership styles to navigate the change processes in the hotel. It is the responsibility of the management to avail the relevant leadership geared towards achieving set goals and objectives highlightened in proposed changes. Existence of leaders with right leadership styles characterized with commitment and support on employees activities and welfare paves a way for a successful implementation of changes in the organization.

\section{Resource Based View Theory}

The theory was developed by Barney in 1991 and forms the basis of developing a competitive environment of a firm. According to the theory, competitive advantage of a firm primarily lies on the application of both intangible and tangible resources in a firm's disposal in executing activities geared towards attaining set performance goals. According to Barney(1991), human resources in the form of technical, financial and physical and organizational resources bears abilities of providing a firm with a sustainable competitive advantage especially when the resources cannot be easily emulated or copied by other firms. The theory postulates that for a firm to stand competitively in the market, the resources need to be heterogeneous but possesses immobility characteristics. This translates into been in possession of valuable resources which can neither be easily imitated nor substituted. The theory further posits that some resources at a firm's disposal contributes to achievement of competitive advantage possessed by firms enables it to achieve competitive advantage while others acts as enablers of realizing exemplary performance. 
High performance and competitive advantage in firms can be achieved and sustained through creating value using means that bear imitability difficulties by competitors. The theory according to Barney (1991) has evolved from an upstart and nascent perspective to being the most powerful and prominent theory for providing explanations on the reasons why some firms progressively post high performances while other post poor performances while exposed to dynamisms in operational environment. The theory contributes to the study by informing the needs of a firm to be in possession of valuable resources to enable the firm adapt to changes in the environment. A changing operational environment calls for a concise adjustments in allocation of resources to activities in a firm for effective realization of set performance goals. In hotel set up, the dynamics in the operational environment characterized by intense competition, changes in demands of customers and technology calls for dedication of key resources to enable the industry to survive. Additionally, realignment of resources in respect to the changing environment contributes significantly towards standing competitively in the market.

\section{Conceptual Framework}

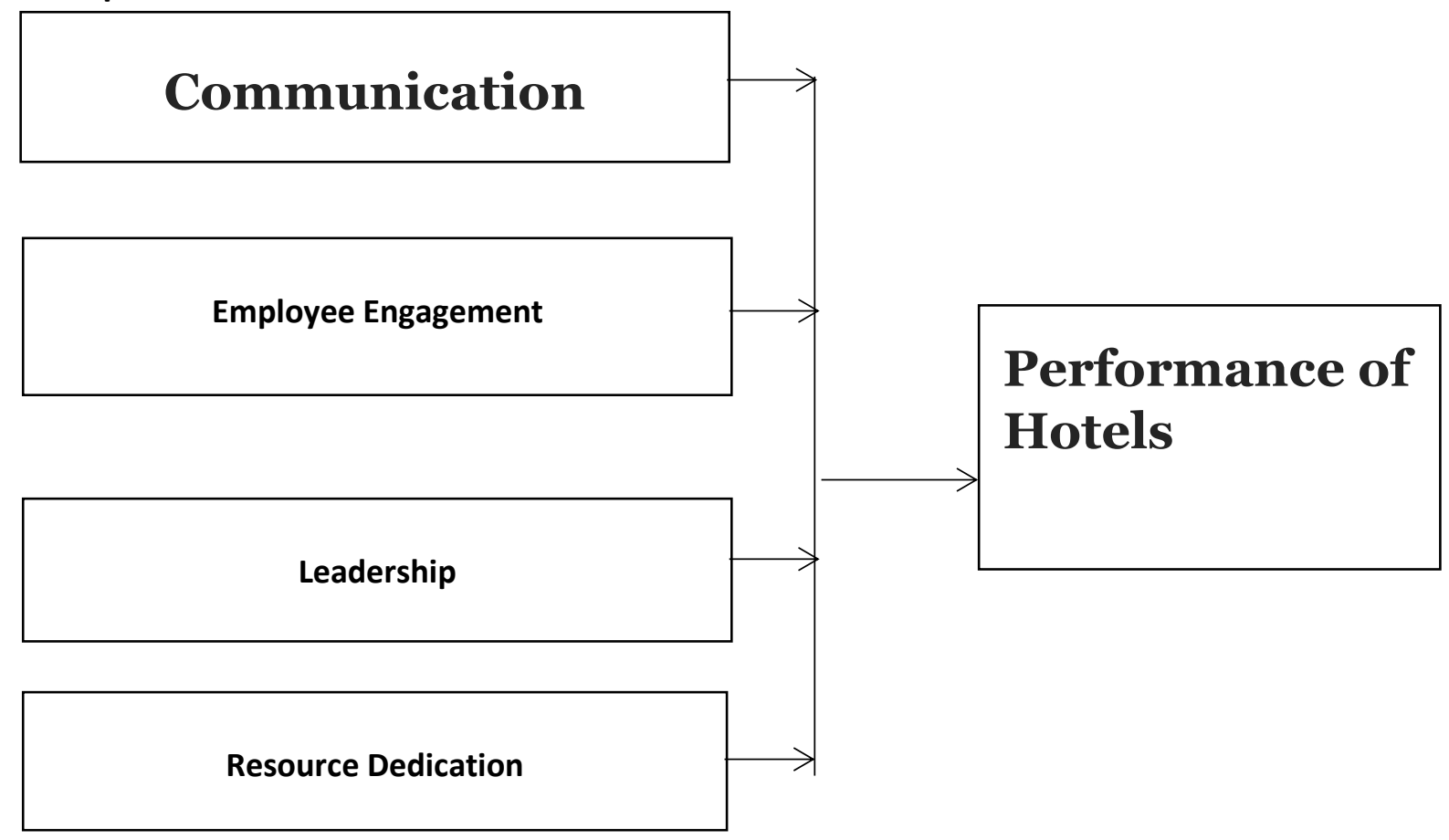

Independent variables

Dependent Variable

Figure 1: Conceptual Framework

\section{Research Methodology}

The study adopted a descriptive research design and targeted 40 hotels operating in Nairobi County and categorized into various levels in form of stars. The unit of observation comprises of one manager, one supervisor and one junior staff in the hotels making a total of 120 respondents. The study used structured questionnaires and secondary data collection sheets to collect both qualitative and quantitative data captured through a 5-point likert scale. Inferential and descriptive statistics was used to analyze data. Results of the analysis were presented by use of tables and figures. Inferential statistics was used to establish the 
association between independent variables and dependent variable. The study used the following regression model:

$Y=\beta_{0}+\beta_{1} X_{1}+\beta_{2} X_{2}+\beta_{3} X_{3}+\beta_{4} X_{4}+\varepsilon$

Where; $Y=$ Performance of Hotels, $\mathrm{X} 1=$ Communication, $\mathrm{X} 2=$ Employee Engagement, $\mathrm{X} 3=$ Leadership, $\mathrm{X} 4=$ Resource Dedication, $\varepsilon=$ Error term, $\beta 0=$ Regression constant or intercept, $\beta 1, \beta 2, \beta 3$ and $\beta 4$ are the unknown coefficients of independent variables.

\section{Results}

The study administered 120 questionnaires where 104 questionnaires were fully filled and returned. This represented a response rate of $86.6 \%$ which was considered adequate, appropriate and sufficient for analysis. The appropriateness of the response rate is supported by assertions from Mugenda and Mugenda (2013) who noted that a response rate of $70 \%$ and above is very good for analysis.

\section{Descriptive Findings and Analysis}

Adoption of descriptive statistics aims at enabling the researcher to describe the distributions of scores or measures. The current study adopted means and standard deviation in presenting the descriptive findings of the study. The criteria followed in adopting the means and standard deviations was first rating the responses using a scale of 1-5 and then presenting the average means and standard deviation. Respondents were presented with statements pertaining to each of the independent variables in the questionnaires and were supposed to provide their ratings of the statements using a scale of 1-5 where $1=$ Strongly Disagree, $2=$ Disagree, $3=$ Neutral, 4= Agree and 5= Strongly Agree.

\section{Communication}

The first objective sought to assess how communication influences performance of hotels. Respondents were provided with statements in regard to communication and were supposed to indicate their levels of agreement. The results presented in table 1 shows that respondents were in agreement with statements that the hotel have established different communication channels for conveying information (mean=4.31, Std.Dev=0.875), that one-on-one mode of communication is used to pass any changes in operations(mean=4.12, Std.Dev=0.984) and that the hotel issues circulars to employees in case of changes in the operations(mean=3.89, Std.Dev=1.026). Additionally, the respondents agreed that the hotels makes information available to all employees (mean $=3.67$, Std. $. \mathrm{ev}=0.931$ ), that there is timely communication in the hotel (mean=4.52, Std.Dev=0.38) and that there is timely communication of feedback to employees (mean=3.61, Std.Dev=1.133).

Finally, the respondents were in agreement with the statements that there is an established communication hierarchy between the management and the employees (mean=3.61, Std.Dev=1.289), that the management ensures there is clarity of information to employees (mean $=4.52$, Std.Dev $=0.38$ ) and that changes in operations was well communicated in coping with Covid times (mean=4.21, Std.Dev=0.23). On average, all the respondents were in agreement with the statement on communication as shown by average response mean of 4.05 and average std.dev of 0.803. The results are in tandem with Bull and Brown (2012) noted that the level of quality of communication bears a significant impact towards achieving change program success since poor exchange of information heightens uncertainty, produces segmented attitude towards work and increases alienation amongst employees. 
Table 1: Descriptive Statistics on Communication

\begin{tabular}{lll}
\hline Statement & Mean & Std.Dev \\
\hline $\begin{array}{l}\text { The hotel have established different communication channels for } \\
\text { conveying information }\end{array}$ & 4.31 & 0.875 \\
$\begin{array}{l}\text { Any change in the operation of the hotel is passed through one-on- } \\
\text { one communication }\end{array}$ & 4.12 & 0.984 \\
$\begin{array}{l}\text { The hotel issues circulars to employees in case of changes in the } \\
\text { operations }\end{array}$ & 3.89 & 1.026 \\
$\begin{array}{l}\text { The hotel makes information available to all employees } \\
\text { Communication in the hotel is passed on timely basis }\end{array}$ & 3.67 & 0.931 \\
$\begin{array}{l}\text { Feedback is timely communicated to employees } \\
\text { There is an established communication hierarchy between the }\end{array}$ & 3.52 & 0.38 \\
$\begin{array}{l}\text { management and the employees } \\
\text { The management ensures there is clarity of information to employees }\end{array}$ & 4.52 & 1.133 \\
$\begin{array}{l}\text { Operational changes were well communicated to cope with Covid -19 } \\
\text { times }\end{array}$ & 4.21 & 0.38 \\
Average & $\mathbf{4 . 0 5}$ & $\mathbf{0 . 8 3}$ \\
\hline
\end{tabular}

\section{Employee Engagement}

The second objective sought to determine how employee engagement influences performance of hotels. Respondents were provided with statements in regard to employee engagement and were supposed to indicate their levels of agreement. The results presented in table 2 shows that respondents were in agreement with statements that employees are involved in the formulation of changes in the hotel(mean=3.89, Std.Dev=1.001), that there is provision of training prior to implementing changes(mean=3.98, Std.Dev=0.856) and that there was engagement of employees in formulating operational procedures to deal with covid(mean=3.99, Std.Dev=1.009). Remarkably, respondents agree that the hotel considers training as a key ingredient to successfully introduce changes(mean=4.35, Std.Dev=0.787), that the hotel awards employees for good performance(mean=3.99, Std.Dev=0.838) and that employees recognition is done in a transparency manner(mean=4.02, Std.Dev=0.652).

However, the respondents were invariant on the fact that they are allowed to participate in decision making processes(mean $=3.45$, Std.Dev=1.141), that their opinions are incorporated in the decision making process(mean=3.39, Std.Dev=1.258) and that the degree of recognition and rewards determines the level of acceptance of changes in the hotel(mean=3.12, Std.Dev=1.459). On average however, the respondents were in agreement with statements on employee engagement as shown by average response mean of 3.80 and average Std.Dev of 1.009. The results are consistent with Harter and Adkins (2015) who established that organizations can engage employees in the change process by applying various means such as seeking employees' opinions on the proposed changes and providing trainings on the proposed changes. 
Table 2: Descriptive Statistics on Employee Engagement

\begin{tabular}{|c|c|c|}
\hline Statement & Mean & Std.Dev \\
\hline Employees are allowed to participate in decision making processes & 3.45 & 1.141 \\
\hline $\begin{array}{l}\text { Opinions from employees are incorporated in the decision making } \\
\text { process }\end{array}$ & 3.39 & 1.258 \\
\hline $\begin{array}{l}\text { There was engagement of employees in formulating operational } \\
\text { procedures to deal with covid-19 }\end{array}$ & 3.99 & 1.09 \\
\hline $\begin{array}{l}\text { There is involvement of employees in the formulation of changes in the } \\
\text { hotel }\end{array}$ & 3.89 & 1.001 \\
\hline There is provision of training prior implementation of changes & 3.98 & 0.856 \\
\hline $\begin{array}{l}\text { The hotel considers training as a key ingredient to successfully introduce } \\
\text { changes }\end{array}$ & 4.35 & 0.787 \\
\hline The hotel awards employees for good performance & 3.99 & 0.838 \\
\hline There is transparency in recognizing employees & 4.02 & 0.652 \\
\hline $\begin{array}{l}\text { The degree of recognition and rewards determines the level of } \\
\text { acceptance of changes in the hotel }\end{array}$ & 3.12 & 1.459 \\
\hline Average & 3.8 & 1.009 \\
\hline
\end{tabular}

\section{Leadership}

The third objective sought to examine how leadership influences performance of hotels. Respondents were provided with statements in regard to leadership and were supposed to indicate their levels of agreement. The results presented in table 3 shows that leaders in the hotels act as the main agents of change (mean=4.21, std.dev=0.541), that they support employees in adapting to changes (mean=4.25, std.dev=0.512), that they take part in the change implementation process (mean $=3.89$, std.dev $=1.004$ ), and that they treats employees with respect so as to create good working relationship(mean=4.14, std.dev=0.801). Consequently, respondents agreed that leaders encourages employees to work together ( mean $=4.36$, std.dev $=0.248$ ), that collaboration with employees is done in consideration to their individuals strengths and weaknesses(mean=3.89, std.dev=0.925), that leaders in the hotels are keen to create a sense of joint mission and ownership of organizational goals and objectives(mean=4.15, std.dev=0.277) and that the leadership of the hotel have put in place measures to ensure compliance with laid down Covid-19 protocols(mean=3.11, std. dev=.793).

The respondents were however invariant on the fact that leaders in the hotel are willing to sacrifice their time and gain to support employees at times of changes(mean=4.23, std.dev=.610). On average, respondents were in agreement with the statements on leadership as shown by average response mean of 4.03 and average std.dev of 0.635 . The results concurs with Ajmal at al., (2014) who highlighted that for business hotel enterprises to promptly and appropriately solve issues associated to changes, the right leadership is a necessity. 
Table 3: Descriptive Statistics on Leadership

\begin{tabular}{|c|c|c|}
\hline Statements & Mean & Std.Dev \\
\hline Leaders in the hotel act as the main agents of change & 4.21 & 0.541 \\
\hline Leaders in the hotel support employees in adapting to changes & 4.25 & 0.512 \\
\hline Leaders in the hotel takes part in the implementation process of changes & 3.89 & 1.004 \\
\hline $\begin{array}{l}\text { Leaders in the hotel treats employees with respect so as to create good } \\
\text { working relationship }\end{array}$ & 4.14 & 0.801 \\
\hline Leaders in the hotel encourages employees to work together & 4.36 & 0.248 \\
\hline $\begin{array}{l}\text { Collaboration with employees is done in consideration to their } \\
\text { individuals strengths and weaknesses }\end{array}$ & 3.89 & 0.925 \\
\hline $\begin{array}{l}\text { Leaders in the hotels are keen to create a sense of joint mission and } \\
\text { ownership of organizational goals and objectives }\end{array}$ & 4.15 & 0.277 \\
\hline $\begin{array}{l}\text { Leaders in the hotel are willing to sacrifice their time and gain to support } \\
\text { employees at times of changes }\end{array}$ & 3.11 & 0.793 \\
\hline $\begin{array}{l}\text { The leadership of the hotel have put in place measures to ensure } \\
\text { compliance with laid down Covid- } 19 \text { protocols }\end{array}$ & 4.23 & 0.610 \\
\hline Average & 4.03 & 0.635 \\
\hline
\end{tabular}

\section{Resource Dedication}

The fourth objective sought to examine how resource dedication influences performance of hotels. Respondents were provided with statements in regard to resource dedication and were supposed to indicate their levels of agreement. The results presented in table 4 shows that the respondents were in agreement with the statements that the hotel allocates sufficient financial resources for change implementation (mean=4.22, std.dev $=0.679$ ), that there is effective management of finances during change process (mean $=4.29$, std.dev $=0.813$ ) and that human capacity is one of the most important ingredient to change process (mean=4.59, std.dev=0.108).

Additionally, respondents agreed that the available human capacity have adequate skills relevant for implementing changes(mean $=4.15$, std.dev $=0.631)$, that the hotel has sets up appropriate technology for change implementation process (mean $=4.1$, std.dev $=0.829$ ), that there exist are trained personnel with technological knowledge to facilitate change implementation process (mean $=4.21$, std.dev $=0.496$ ) and that there has been a reduction in human resources during Covid-19 pandemic(mean=4.79, std.dev=0.096). The respondents were however invariant with the fact that there hotel has adequate human capacity to implement changes (mean=3.33, std.dev=1.121). On average however, the respondents were in agreement with the statements on resource dedication as shown by average response mean of 4.13 and average std.dev of 0.668. the results are in tandem with Monnot (2016) who hypothesized that for effective implementation of changes, a firm requires essential resources inclusive of financial, human, and technological resources. 
Table 4: Descriptive Statistics on Resource Dedication

\begin{tabular}{llcc}
\hline Statements & Mean & Std.Dev \\
\hline The hotel allocates sufficient financial resources for change & 4.22 & 0.679 \\
implementation & 4.29 & 0.813 \\
There is effective management of finances during change process & 3.33 & 1.121 \\
There is adequate human capacity to implement changes in the hotel & 4.59 & 0.108 \\
$\begin{array}{l}\text { Human capacity is one of the most important ingredient to change process } \\
\text { The available human capacity have adequate skills relevant for }\end{array}$ & 4.15 & 0.631 \\
$\begin{array}{l}\text { implementing changes } \\
\text { The hotel has sets up appropriate technology for change implementation }\end{array}$ & 4.1 & 0.829 \\
$\begin{array}{l}\text { process } \\
\text { There are trained personnel with technological knowledge to facilitate }\end{array}$ & 4.21 & 0.496 \\
$\begin{array}{l}\text { change implementation process } \\
\text { There has been a reduction in human resources during Covid-19 pandemic }\end{array}$ & 4.79 & 0.096 \\
Average & $\mathbf{4 . 2 1}$ & $\mathbf{0 . 5 9 7}$ \\
\hline
\end{tabular}

\section{Performance of Hotels}

The study sought to analyze the performances of the hotels in terms of hotel occupancy, customer satisfaction index, profit before tax and return on investments from 2015-2019. The first section sought to establish the hotel occupancy rate. The results presented in table 5 shows that in 2015, 26.1\% of the hotels had an occupancy rate of below $20 \%, 27.1 \%$ had between $20 \%-40 \%$ occupancy rates, $10.2 \%$ had between $41 \%$ and $60 \%$ occupancy while $36.6 \%$ had an occupancy rate of above $60 \%$. In $2016,26.1 \%$ had an occupancy rates of below $20 \%$, $27.1 \%$ had between $20 \%$ and $40 \%$ occupancy rate, $10.2 \%$ had between 41 \& and $60 \%$ while $36.6 \%$ had above $60 \%$.

In $2017,57.5 \%$ had below $20 \%$ occupancy rate, 27.6 between $20 \%$ and $40 \%, 9.4 \%$ had between $41 \%$ and $60 \%$ while $5.5 \%$ had above $60 \%$ occupancy rate. In 2018 , occupancy rate below $20 \%$ was $46.3 \%$, between $20 \%$ and $40 \%$ was $26.8 \%$, between $41 \%$ and $60 \%$ was $17.9 \%$ while above $60 \%$ was $9 \%$. In 2019 , occupancy rate below $20 \%$ was $27.1 \%$, between $20 \%$ and $40 \%$ was $18.2 \%$, between $41 \%$ and $60 \%$ was $20.1 \%$ while above $60 \%$ was $34.6 \%$. The results shows varying occupancy rates of hotels with 2019 having the highest occupancy and 2017 having the lowest occupancy rate.

Table 5: Hotel Occupancy Rate

\begin{tabular}{lllll}
\hline Year & Below 20\% & $\mathbf{2 0 \% - 4 0 \%}$ & $\mathbf{4 1 \% - 6 0 \%}$ & Above 60\% \\
\hline $\mathbf{2 0 1 5}$ & $26.10 \%$ & $27.10 \%$ & $10.20 \%$ & $36.60 \%$ \\
$\mathbf{2 0 1 6}$ & $26.10 \%$ & $27.10 \%$ & $10.20 \%$ & $36.60 \%$ \\
$\mathbf{2 0 1 7}$ & $57.50 \%$ & $27.60 \%$ & $9.40 \%$ & $5.50 \%$ \\
$\mathbf{2 0 1 8}$ & $46.30 \%$ & $26.80 \%$ & $17.90 \%$ & $9 \%$ \\
$\mathbf{2 0 1 9}$ & $27.10 \%$ & $18.20 \%$ & $20.10 \%$ & $34.60 \%$ \\
\hline
\end{tabular}

The second section sought to establish the level of customer satisfaction index. Respondents were requested to indicate the index in respect to customer's online rating where one starvery low satisfaction, two stars-low satisfaction, three stars-moderate satisfaction, four starshigh satisfaction and five stars- very high satisfaction. The results in table 6 shows that in both 2015 and 2016, the ratings from customers indicates that $23.6 \%$ of the hotels were rated as 
moderately satisfying, $27.9 \%$ had high satisfaction index while $48.5 \%$ had very high satisfaction index.

In $2017,10.8 \%$ of the hotels were rated as low satisfying, $20.6 \%$ with moderately satisfying, $24.9 \%$ had high satisfaction index while $43.7 \%$ had very high satisfaction index. In $2018,11.9 \%$ of the hotels were rated as moderately satisfying, $20 \%$ had high satisfaction index while $68.1 \%$ had very high satisfaction index. In $2019,6 \%$ of the hotels were rated as moderately satisfying, $30.8 \%$ had high satisfaction index while $63.2 \%$ had very high satisfaction index. The results shows that the hotels had a high satisfaction rates in the years considered in the study. This is attributable to implementation of competitive approaches that tends to attract customers.

Table 6: Customer Satisfaction Index

Year Customer Satisfaction Index

\begin{tabular}{|c|c|c|c|c|c|}
\hline & $\begin{array}{l}\text { Very low } \\
\text { satisfaction }\end{array}$ & $\begin{array}{l}\text { Low } \\
\text { satisfaction }\end{array}$ & $\begin{array}{l}\text { Moderate } \\
\text { satisfaction }\end{array}$ & $\begin{array}{l}\text { High } \\
\text { satisfaction }\end{array}$ & $\begin{array}{l}\text { Very high } \\
\text { satisfaction }\end{array}$ \\
\hline 2015 & 0 & 0 & $23.60 \%$ & $27.90 \%$ & $48.50 \%$ \\
\hline 2016 & 0 & 0 & $23.60 \%$ & $27.90 \%$ & $48.50 \%$ \\
\hline 2017 & 0 & $10.80 \%$ & $20.60 \%$ & $24.90 \%$ & $43.70 \%$ \\
\hline 2018 & 0 & 0 & $11.90 \%$ & $20.00 \%$ & $68.10 \%$ \\
\hline 2019 & 0 & 0 & $6.00 \%$ & $30.80 \%$ & $63.20 \%$ \\
\hline
\end{tabular}

The third section sought to establish the levels of profits before taxes of the hotels under study. The results presented in table 7 shows that in 2015, the hotels whose profit before tax (PBT) was below ksh500million were $28.4 \%$, between ksh $500 \mathrm{~m}$ and ksh1billion were $24.6 \%$, between ksh1billion and ksh 1.5billion were 19.9\%, between ksh $1.5 \mathrm{~b}$ and ksh $2 \mathrm{~b}$ were $13 \%$ while those above ksh $2 \mathrm{~b}$ were $14.1 \%$. In 2016, the hotels whose profit before tax (PBT) was below ksh500million were $15.9 \%$, between ksh 500m and ksh1billion were $22.4 \%$, between ksh1billion and ksh 1.5 billion were $27.5 \%$, between ksh $1.5 \mathrm{~b}$ and ksh $2 \mathrm{~b}$ were $14.9 \%$ while those above ksh $2 b$ were $19 . \%$.

In 2017, the hotels whose profit before tax (PBT) was below ksh500million were $54.9 \%$, between ksh $500 \mathrm{~m}$ and ksh1billion were $14.4 \%$, between ksh1billion and ksh 1.5billion were $13.9 \%$, between ksh $1.5 \mathrm{~b}$ and ksh $2 \mathrm{~b}$ were $10.6 \%$ while those above ksh $2 \mathrm{~b}$ were $6.3 \%$.In 2018 , the hotels whose profit before tax (PBT) was below ksh500million were $302 \%$, between ksh $500 \mathrm{~m}$ and ksh1billion were $37.4 \%$, none between ksh1billion and ksh 1.5 billion, between ksh $1.5 \mathrm{~b}$ and ksh $2 \mathrm{~b}$ were $20.9 \%$ while those above ksh $2 \mathrm{~b}$ were $11.5 \%$. In 2019 , the hotels whose profit before tax (PBT) was below ksh500million were $12.6 \%$, between ksh $500 \mathrm{~m}$ and ksh1billion were 19.2\%, between ksh1billion and ksh 1.5billion were $20 \%$, between ksh $1.5 \mathrm{~b}$ and ksh $2 \mathrm{~b}$ were $26.9 \%$ while those above ksh $2 \mathrm{~b}$ were $21.3 \%$. The results indicates variances in the performances of the hotels where 2019 recorded the highest levels of performances while 2017 had the lowest performances. The high performance level in 2019 can be associated with high occupancy rate recorded in the same year. 
Table 7: Profit Before Tax

\begin{tabular}{|c|c|c|c|c|c|c|}
\hline Year & $\begin{array}{l}\text { Below } \\
500 \text { million }\end{array}$ & ksh & $\begin{array}{l}\text { Ksh500m- } \\
\text { ksh1b }\end{array}$ & $\begin{array}{l}\text { Ksh1b- } \\
\text { ksh1.5b }\end{array}$ & $\begin{array}{l}\text { Ksh1.5b- } \\
\text { ksh2b }\end{array}$ & $\begin{array}{l}\text { Above } \\
\text { ksh2b }\end{array}$ \\
\hline 2015 & $28.4 \%$ & & $24.6 \%$ & $19.9 \%$ & $13.0 \%$ & $14.1 \%$ \\
\hline 2016 & $15.9 \%$ & & $22.4 \%$ & $27.5 \%$ & $14.9 \%$ & $19.3 \%$ \\
\hline 2017 & $54.9 \%$ & & $14.4 \%$ & $13.9 \%$ & $10.6 \%$ & $6.2 \%$ \\
\hline 2018 & $30.2 \%$ & & $37.4 \%$ & $0.0 \%$ & $20.9 \%$ & $11.5 \%$ \\
\hline 2019 & $12.6 \%$ & & $19.2 \%$ & $20.0 \%$ & $26.9 \%$ & $21.3 \%$ \\
\hline
\end{tabular}

The fourth section sought to establish the performance levels of hotels in terms of return on investments. Figure 2 shows that the ROI of hotel in 2015 for the hotels stood at $34.9 \%$ which increased to $36.7 \%$ in 2016 . In 2017 , the returns decreased to $21.4 \%$ which was followed by an increasing trend of $29.8 \%$ and $38.9 \%$ in 2018 and 2019 respectively. The results shows that the hotel have been experiencing varying performances from 2015 through 2019.

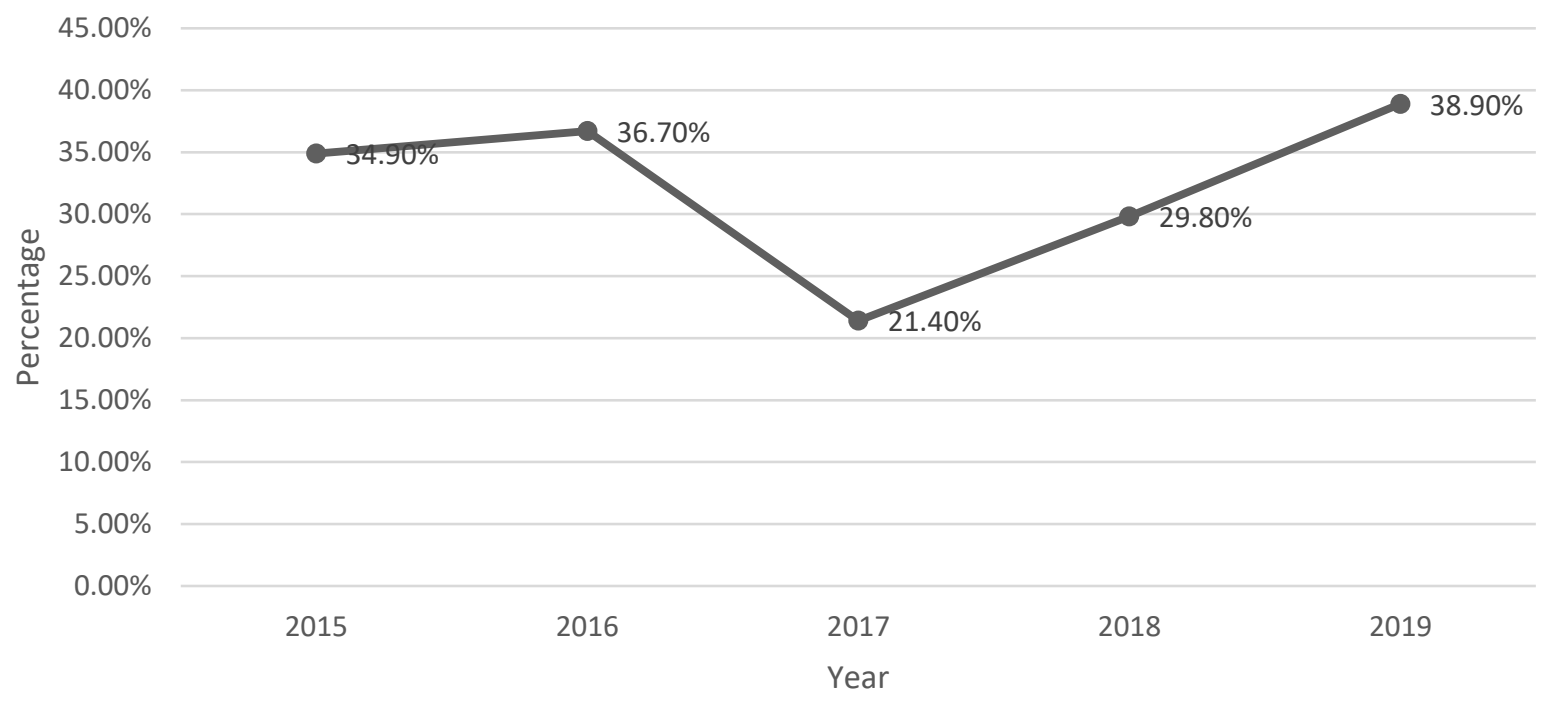

Figure 2: Return on Investment

\section{Multiple Regression Analysis}

The analysis of variance (ANOVA) was conducted to test whether the model used in the study was statistically significance in testing the relationships variables of the study. The results shown in table 8 shows that the model was statistically significant. The significance level is justified by comparing the calculated value of $F$ which is 15.1802 and $F$ critical value at $(4,99)$ which is 2.46. The value of $F$ calculated exceeds the value of $F$ critical thus confirming the statistical significance of the model.

Table 8: ANOVA (Model Significance)

\begin{tabular}{lllllll}
\hline \multicolumn{1}{l}{ Model } & Sum of Squares & Df & \multicolumn{2}{l}{ Mean Square F } & Sig. \\
\hline 1 & Regression & 42.268 & 4 & 10.567 & 15.1802 & $1.210^{\mathrm{b}}$ \\
& Residual & 68.918 & 99 & 0.6961 & & \\
& Total & 111.186 & 103 & & & \\
\hline
\end{tabular}

Table 9 presents the coefficients of the model used in the study. According to the results, communication influences the performance of the hotels to a positive and significant level. 
This is depicted by a beta value of 0.298 and Sig value of 0.012 . This implies that increasing communication practices with one unit results to 0.298 units increase in performance levels of hotels. This is in line with Alshahrani (2019) who established that provision of proper and sufficient communication during the change process serves as a key prerequisite for proper employees' preparedness which catalyzes their performances. The coefficient results also shows that employee engagement influences the performance of the hotels to a positive and significant level. This is depicted by a beta value of 0.321 and Sig value of 0.009 . The results implies that increasing employee engagement practices with one unit increases the performance of the hotels with 0.321 units. The results concurs with Muthike (2017) who established that involvement of employees by management while making decisions significantly contributes to high employee commitment thus enhanced performance.

The coefficient results further shows that leadership influences the performance of the hotels to a positive and significant level. This is depicted by a beta value of 0.387 and Sig value of 0.002. The results implies that increasing leadership practices with one unit increases the performance of the hotels with 0.387 units. The results concurs with Ajmal at al., (2014) who highlighted that for business hotel enterprises to promptly and appropriately solve issues associated to changes, the right leadership is a necessity. The coefficient results finally shows that resource dedication influences the performance of the hotels to a positive and significant level. This is depicted by a beta value of 0.459 and Sig value of 0.000 . The results implies that increasing resource dedication with one unit increases the performance of the hotels with 0.459 units. The results are in consistent with Omollo, Christopher, and Onyango(2017) who revealed that resource allocation and appropriate utilization contributes significantly to the performance of firms.

Table 9: Model Coefficients

\begin{tabular}{llllll}
\hline & \multicolumn{3}{l}{ Unstandardized Coefficients } & \multicolumn{3}{l}{ Standardized Coefficients } \\
\hline Predictors & B & Std. Error & Beta & T & Sig. \\
\hline (Constant) & 0.254 & 0.075 & & 3.3867 & 0.103 \\
Communication & 0.298 & 0.146 & 0.555 & 2.0411 & 0.012 \\
Employee Engagement & 0.321 & 0.156 & 0.201 & 2.0577 & 0.009 \\
Leadership & 0.387 & 0.127 & 0.286 & 3.0472 & 0.002 \\
Resource Dedication & 0.459 & 0.098 & 0.941 & 4.6837 & 0.000 \\
\hline
\end{tabular}

The model therefore becomes;

Performance of Hotels $=0.254+0.459$ (Resource Dedication) +0.387 (Leadership) + 0.321 (Employee Engagement) +0.298 (Communication)

The model results shows that resource dedication bears the most significant influence on performance, followed by leadership, then employee engagement and finally communication.

A multiple regression analysis was conducted to assess the degree of relation between the study variables. The analysis was conducted at $95 \%$ confident level. According to the results in table 10, there exist a strong relationship between Communication, Employee Engagement, Leadership and Resource Dedication and performance of hotels as depicted by $R=0.859$. The R-Squared value which represents the coefficient of determination was 0.738 implying that Communication, Employee Engagement, Leadership and Resource Dedication accounts for $73.8 \%$ of performance of hotels. 
Table 10 Model Summary

\begin{tabular}{llll}
\hline R & R Square & Adjusted R Square & $\begin{array}{l}\text { Std. Error of the } \\
\text { Estimate }\end{array}$ \\
\hline $.859^{\mathrm{a}}$ & 0.738 & 0.701 & 1.001265 \\
\hline
\end{tabular}

a. Predictors: (Constant), Communication, Employee Engagement, Leadership and Resource Dedication

\section{Conclusion}

The study findings led to conclusions that resource dedication bears the highest positive and significant influence on performance levels of hotels in Kenya. Additionally resource dedication practices such as allocating sufficient financial resources for change implementation, having an effective management of finances during change process, having human capacity with adequate skills relevant for implementing changes, setting up appropriate technology for change implementation process and having trained personnel with technological knowledge to facilitate change implementation process significantly and positively influences performances of hotels in Kenya. The study findings further led to conclusions that leadership positively and significantly influences performance levels of hotels in Kenya. Additionally, leadership practices by leaders of hotels such as acting as the main agents of change, leaders support employees in adapting to changes, taking part in the implementation process of changes, treating employees with respect so as to create good working relationship, encouraging employees to work together, collaborating with employees by consideration their individuals strengths and weaknesses and been keen in creating a sense of joint mission and ownership of organizational goals and objectives significantly and positively influences performances of hotels in Kenya.

The study findings also led to conclusions that employee engagement positively and significantly influences performance levels of hotels in Kenya. Additionally, employee engagement practices such as engaging employees in formulating operational procedures to deal with covid-19, involving employees in the formulation of changes in the hotel, provision of training prior implementation of changes, considering training as a key ingredient to successfully introduce changes, awarding employees for good performance and having transparency in recognizing employees significantly and positively influences performances of hotels in Kenya. The study findings finally led to conclusions that communication positively and significantly influences performance levels of hotels in Kenya. Additionally, communication practices such as establishing different information conveying channels, communicating operational changes through one-on-one mode, issuing circulars to employees on operational changes, availing timely information and feed back to all employees, and ensuring there is clarity of information to employees significantly and positively influences performances of hotels in Kenya.

\section{Recommendations for the Study}

The study recommends to the management of hotels to enhance their resource dedication practices when implementing changes since the practice positively and significantly influence performances of the hotels. The hotels can achieve this by dedicating both financial, human and technological resources in the change implementation process to enhance change implementation success that will led to increased performance levels. Consequently, the management of the hotels are encouraged to portray right leaderships practices during the 
change implementation process since the practice positively and significantly influence performance of the hotels. Adoption of transformative, participative and transactional leadership styles ensures provision of the right leadership gearing towards enhancing the success of the change process for the benefit of the hotels performance.

Remarkably, there is a need to enhance employee engagement practices in the hotels since the practice influences performance of the hotels to a positive and significant level. This can be achieved by ensuring that all employees are fully involved in the implementation of changes for them to be informed on the performance objectives resulting from the change. The hotels are finally recommended to enhance their communication practices during the change process to affected parties especially the employees since the practice positively and significantly influences the level of performance of hotels. Establishing communication practices such as having different communication channels, providing clarity on issues and providing timely feedback ensures a smooth flow of information in the hotels that translates to realization of set change performance goals.

\section{References}

Ajmal, S., Farooq, Z., Sajid, N., \& Awan, S. (2014). Role of Leadership in Change Management Process. Abasyn Journal Of Social Sciences, 5(2), 111-124.

Al-Asoufi, B., \& Akhorshaideh, A. (2017). The Impact of Employee Empowerment on the Success of Organizational Change: A Study in Privatized Enterprises in Jordan. Journal Of Public Administration And Governance, 7(1), 87-101.

Alshahrani, M. (2019). The organizational change impact on the employee's behaviour and performance in KSA universities. Multi-Knowledge Electronic Comprehensive Journal For Education And Science Publications, (16), 1-22.

Barney, M. (1991). The Resource-based Theory of Competitive Advantage: Implications for Strategy Implementation

Boucekkine, R., \& Crifo, P. (2012). Technological Progress, Organizational Change and the Size of the Human Resources Department. SSRN Electronic Journal, 6(12), 122-138.

Bull, M., and Brown, T. (2012). Change communication: the impact on satisfaction with alternative workplace strategies. Facilities, 30 (34), 135 - 151.

Chapman, B. (2015). "Researching the roles of internal-change agents in the management of organizational change", British Journal of Management, 8 (1), 61.

Crane, L. (2010). A survey of change management practices in Singapore, Information management Review,39(2),125-134

Eisenbach, R., Watson, K., \& Pillai, R. (2010). Transformational leadership in the context of organizational change. Journal of Organizational Change Management, 12(2), 80 - 89.

El-Dirani, A., Hejase, H., \& Hussein, M. (2019). The Role of Human Resources in Change Management: An Exploratory Study in Lebanon. The Journal Of Middle East And North Africa Sciences, 5(6), 1-13.

Evans, M. G. (1970). The effects of supervisory behavior on the path-goal relationship. Organizational Behavior and Human Performance. 5: 277-298.

Femi, A. (2014). The Impact of Communication on Workers' Performance in Selected Organisations in Lagos State, Nigeria. Journal Of Humanities And Social Science, 19(8), 75-82.

Fleenor, J. W., Day, D. V., Atwater, L. E., Sturm, R. E., \& McKee, R. A. (2014). Advances in leader and leadership development: Leadership Quarterly. 25 (1), 63-82. 
Fok-Yew, O., \& Ahmad, H. (2014). The Effect of Change Management on Operational Excellence in Electrical and Electronics Industry: Evidence from Malaysia. British Journal Of Economics, Management \& Trade, 4(8), 1285-1305.

Gathara, S. (2018). Effect Of Strategic Management Practices On Organizational Performance In The Hotel Industry- Nairobi, Kenya (MBA Project). United States International University - Africa.

Harter, J., and Adkins, A. (2015). What Great Managers Do to Engage Employees?

Hilman, H., \& Mohamed, Z. A. (2011). Sourcing strategies, practices and effects on organizational performance. Journal of Global Business Advancement, 4(1), 1831.

House, R. J., Mitchell, T. R. (1974). Path-goal theory of leadership. Journal of Contemporary Business. 3: I-97.

Mason, R. O. (1978). Measuring information output: A communication systems approach. Information \& Management, 1(4), 219-234.

McAdam, M. L., \& Walker, A., Hazlett, J. A. (2011).The strategic implementation process: evoking strategic consensus through communication, Journal of Business Research, 55(6), 301-310

Monnot, M. (2016). Organizational Change Agent Influence: A Conditional Process Model of Key Individual Psychological Resources. Journal Of Change Management, 17(3), 268295.

Mugenda, O., \& Mugenda, A. (2013). Research methods. Nairobi, Kenya: African Centre for Technology Studies.

Muhinyu, N., \& Gudda, P. (2019). Competitive Strategies Adopted by Hotels in Kenya and Their Effects on Financial Performance: A Case of Serena Hotels. The International Journal Of Business \& Management, 7(5).

Muthike, C. (2017). The Impact of Employee Engagement On Organization Performance: A Case Of Pact, Nairobi (Masters). United States International University - Africa.

Mutiso, G. (2017). Change Management Communications: A Case Of Ps Kenya's Orion Project (Masters). United States International University.

Njagi, E., Muchemi, A., \& Muathe, S. (2018). Financial Resources, Physical Resources and Performance of Public Health Institutions in Embu County, Kenya. European Journal Of Business And Management, 10(8), 41-47.

Northouse, G. (2013). Leadership theory and practice. (3rd Ed.) Thousand Oaks, CA: Sage Publications

Ogohi, D. (2019). Effects of Change Management on the Performance of Firms in Nigeria. International Journal Of Advances In Scientific Research And Engineering, 5(1), 59-64.

Omollo, N., Christopher, N., \& Onyango, Y. (2017). Determining The Effects Of Resource Allocation On The Performance Of South Nyanza Sugar Company Limited, Kenya. International Journal of Social Sciences And Information Technology, 3(9), 2514-

Panda, S. (2011). Performance Management System: Issues and Challenges. Management And Labour Studies, 36(3), 271-280.

Pillay, E., \& Singh, S. (2018). The Impact of employee engagement on organisational performance - a case of an Insurance Brokerage company in Gauteng. Journal of Business And Management, 20(6), 66-76.

Schuler, R.(1990). A path-goal theory of leadership (3rd ed.). New York: Sage. 
Shannon, C., \& Weaver, W. (1949).The Mathematical Theory of Communication. Urbana: University of Illinois Press.

Tourism Authority. (2020). Downloads. Retrieved 13 June 2020, from https://www.tourismauthority.go.ke/index.php/resource-centre/downloads

Wachira, L., \& Anyieni, A. (2017). Effect of Change Management Practices on Performance of Teachers Service Commission. International Journal Of Science And Research, 6(5), 525-531. 